\title{
PEMBERDAYAAN MASYARAKAT BERBASIS COASTAL RESOURCES MANAGEMENT (CRS) DALAM MENINGKATKAN TARAF HIDUP MASYARAKAT ADAT PESISIR PANTAI DI DESA MALIKIAN KALIMANTAN BARAT
}

\author{
Heriansyah ${ }^{1}$, Gandha Sunaryo Putra ${ }^{2}$, Hendri Yanto ${ }^{3}$, Linda Suwarni ${ }^{4}$, Ufi Ruhama ${ }^{5}$ \\ 1,2,3,4,5 Universitas Muhammadiyah Pontianak \\ email:gandhasunaryoputra90@gmail.com
}

\begin{abstract}
ABSTRAK
Desa Malikian merupakan suatu desa yang terletak di pesisir pantai Kabupaten Mempawah. Desa ini memiliki sumber daya perikanan dan kelautan yang melimpah karena letaknya di pesisir laut. Potensi tersebut dimanfaatkan oleh masyarakat yang bermata pencaharian sebagai nelayan. Di desa ini memiliki beberapa kelompok pengolah pemasar (POKLAHSAR) hasil perikanan dan kelautan dan kelompok tani, sehingga potensi tersebut dapat dikembangkan dan menjadi wadah dalam peningkatkan keterampilan dan pengolahan hasil alam dalam rangka meningkatkan ekonomi masyarakat sekitar.

Namun, ditemukan beberapa masalah di desa ini diantaranya masih banyaknya masyarakat yang berobat ke dukun, tingginya angka kejadian diare dan ISPA, masalah air bersih, pergaulan bebas remaja, tingginya angka pernikahan dini yang disebabkan kehamilan yang tidak diinginkan, dan penggunaan narkoba. Masalah lainnya yang ditemukan di desa ini adalah pengolahan hasil laut dan pertanian masih bersifat tradisional. Hal ini menyebabkan produktifitas menjadi terbatas, padahal permintaan pasar terhadap produk sangat tinggi.

Tujuan yang ingin dicapai dari kegiatan ini adalah meningkatkan taraf hidup masyarakat pesisir pantai melalui peningkatkan sosial kemasyarakat, perekonomian serta kesehatan masyarakat. Metode pelaksanaan yang akan digunakan dalam pengabdian ini adalah sosialisasi, penyuluhan, pelatihan, dan demonstrasi kelompok dengan konsep pemberdayaan masyarakat berbasis Coastal Resources Management (CRS) pada masyarakat adat pesisir pantai di Desa Malikian Kalimantan Barat.

Hasil dari kegiatan ini adalah telah terlaksananya peningkatan pendidikan keagamaan melalui kegiatan sosialisasi dan pembentukan remaja Masjid Nurul Iman, pembinaan remaja masjid dan tata kelola pendidikan quran. Telah terlaksananya peningkatan gerakan masyarakat hidup sehat (GERMAS) melalui kegiatan lokakarya mini, promosi kesehatan perilaku hidup bersih dan sehat (PHBS), kesehatan reproduksi remaja, sanitasi lingkungan dan tanaman obat keluarga (TOGA), pembuatan media penyaringan air bersih percontohan, pembuatan media dan praktik cuci tangan pakai sabun (CTPS). Terlaksananya kegiatan kewirausahaan ekonomi pertanian dan perikanan melalui kegiatan musyawarah masyarakat desa (MMD), pembinaan kelompok POKLAHSAR, pelatihan pengolahan, packing produk, dan pemasaran hasil perikanan dan perkebunan dan pembuatan kolam terpal percontohan.
\end{abstract}

Kata Kunci: Desa Malikian, Coastal Resources Management (CRS), Pemberdayaan, Masyarakat Pesisir, POKLAHSAR, Germas 
ISSN : $2620-4665$ (print)

ISSN : 2620 - 4673 (online)

Website : http://jurnal.untan.ac.id/index.php/JPLP2KM

\section{PENDAHULUAN}

Sumber daya manusia yang sehat dan berkualitas merupakan salah satu modal utama atau investasi dalam pembangunan kesehatan. Bidang kesehatan dan ekonomi menjadi pilar yang sangat mempengaruhi kesejahteraan hidup manusia. Indeks Pembangunan Manusia (IPM) merupakan salah satu indikator pencapaian pembangunan di suatu negara, dimana Indonesia pada tahun 2013 menduduki peringkat 113 (IPM 0,689) dari 188 negara di dunia (United Nations Development Programme, 2017). Terdapat tiga dimensi utama yang digunakan sebagai dasar evaluasi IPM, diantaranya adalah "hidup panjang yang sehat", "akses terhadap ilmu pengetahuan", dan "standard kehidupan yang layak".

Kalimantan Barat merupakan salah satu propinsi dengan IPM menduduki peringkat ke 31 diantara 35 propinsi di Indonesia. Hal ini menunjukkan bahwa daerah ini membutuhkan peningkatan di semua sektor, di antaranya adalah sektor kesehatan, pendidikan dan ekonomi. Beberapa daerah di Kalimantan Barat perlu mendapat perhatian khusus, seperti daerah-derah tertinggal di pinggiran, pesisir, dan kepulauan Kalimantan Barat (Badan Pusat Statistik, 2018).

Salah satu wilayah pesisir Kalimantan Barat adalah Kabupaten Mempawah. Kabupaten Mempawah merupakan salah satu kabupaten yang ada di Kalimantan Barat dengan IPM menduduki peringkat ke 12 dari 14 kabupaten/kota yang ada di Kalimantan Barat (Badan Pusat Statistik, 2018).

Desa Malikian merupakan salah satu desa di Kabupaten Mempawah yang terletak di pesisir pantai. Mayoritas penduduknya adalah masyarakat suku adat yang bekerja sebagai nelayan dan petani yang memenuhi kebutuhannya dari sumber daya di pesisir pantai. Masyarakat yang tinggal di daerah pesisir pantai adalah para nelayan tradisional yang oleh karena ketidakberdayaannya dalam segala aspek, baik materi, pengetahuan, maupun teknologi, menjadikan mereka miskin dan tertinggal (Suhartono, 2007).

Berdasarkan analisis situasi, beberapa permasalahan yang ada di Desa Malikian antara lain dalam bidang sosial kemasyarakatan, kesehatan, dan perekonomian. Dalam bidang sosial kemasyarakatan, di desa ini memiliki permasalahan mengenai pergaulan remaja yang bebas dan banyak remaja yang sudah mulai mengenal narkoba. Selain itu, permasalahan lain yang tidak kalah penting adalah mulai meningkatnya angka pernikahan dini (menikah sebelum usia 20 tahun) di daerah ini. Riset Kesehatan Dasar yang dilakukan Kementerian Kesehatan RI mengungkapkan bahwa 2,6\% perempuan yang berusia 10-54 tahun menikah pertama kali pada umur kurang dari 
15 tahun, dan 23,9\% menikah pada umur 15-19 tahun. Ini berarti sekitar 26\% perempuan di bawah umur telah menikah sebelum fungsi-fungsi organ reproduksinya berkembang dengan optimal (Kemenkes RI, 2013).

Sementara itu, permasalahan dalam bidang kesehatan yang ada di Desa Malikian antara lain kurangnya kesadaran masyarakat dalam menerapkan Perilaku Hidup Bersih dan Sehat (PHBS).. Pada musim kemarau masyarakat di desa ini kesulitan mendapatkan air bersih karena kualitas air yang kurang baik. Masalah kesehatan lainnya yang ada di desa ini diantaranya adalah kasus ISPA sebesar 56\%, diare sebesar $46 \%$, kecacingan pada anak SD sebesar $37 \%$ dan penyakit kulit sebesar $48 \%$. Masalah kesehatan yang lainnya jamban sehat hanya sebesar $72,2 \%$, perilaku merokok di dalam rumah sebesar $63 \%$, cakupan kunjungan posyandu sebesar $72 \%$, dan persalinan di tenaga kesehatan sebesar $82 \%$. Hal ini disebabkan perilaku masyarakat yang kurang menerapkan hidup bersih dan sehat baik di rumah tangga maupun di sekolah.

Status ekonomi masyarakat di Desa Malikian umumnya menengah ke bawah. Sebagian besar masyarakat bermata pencaharian sebagai nelayan. Lahan yang ada hanya dimanfaatkan untuk menanam padi, sedangkan selebihnya belum dimanfaatkan dengan baik. Di Desa ini terdapat beberapa kelompok ibu-ibu yang mengolah hasil perikanan menjadi produk kerupuk, bakso ikan, ikan asin, dan lain-lain. Namun, sistem pengolahan yang masih bersifat tradisional menyebabkan masih rendahnya hasil produksi.

Sistem pemasaran yang dilakukan selama ini hanya bersifat lokal. Padahal, permintaan pasar terhadap produk tersebut cukup tinggi. Dalam hal pengemasan produk, selama ini ibu-ibu menggunakan plastik es biasa dan direkatkan dengan menggunakan api, sehingga kemasan kurang menarik. Diperlukan pengetahuan dan introduksi teknologi alat kemasan agar produk yang dihasilkan dapat dikemas dengan menarik agar dapat meningkatkan nilai jual dari produk.

Berdasarkan pemaparan diatas, maka diperlukan pemberdayaan masyarakat berbasis Coastal Resources Management (CRS) untuk meningkatkan taraf hidup masyarakat suku adat pesisir pantai di Desa Malikian Kalimantan Barat. Tujuan yang ingin dicapai dari kegiatan ini adalah meningkatkan taraf hidup masyarakat pesisir pantai melalui peningkatkan sosial kemasyarakat, perekonomian serta kesehatan masyarakat. 
ISSN : $2620-4665$ (print)

ISSN : 2620 - 4673 (online)

Website : http://jurnal.untan.ac.id/index.php/JPLP2KM

\section{METODE PELAKSANAAN KEGIATAN}

\subsection{Metode Pelaksanaan}

Metode yang digunakan dalam melaksanakan kegiatan ini adalah dengan melakukan pemberdayaan kelompok sasaran yang bersifat partisipatif dan dialogis. Pendekatan partisipatif dan dialogis dilakukan antar masyarakat yang difasilitasi oleh Tim pelaksana kegiatan dengan melakukan analisis masalah secara bersama-sama dalam rangka merumuskan kegiatan yang akan dilakukan tersebut. Langkah-Langkah dalam bentuk program yang akan dilaksanakan untuk mencapai hasil yang diharapkan dari tema KKN-PPM

\subsection{Tempat dan Waktu Kegiatan}

Kegiatan ini dilaksanakan di Desa Malikian Kabupaten Mempawah. Waktu pelaksanaan kegiatan ini dilaksanakan pada Bulan Juli-September 2019.

\subsection{Tahapan Kegiatan}

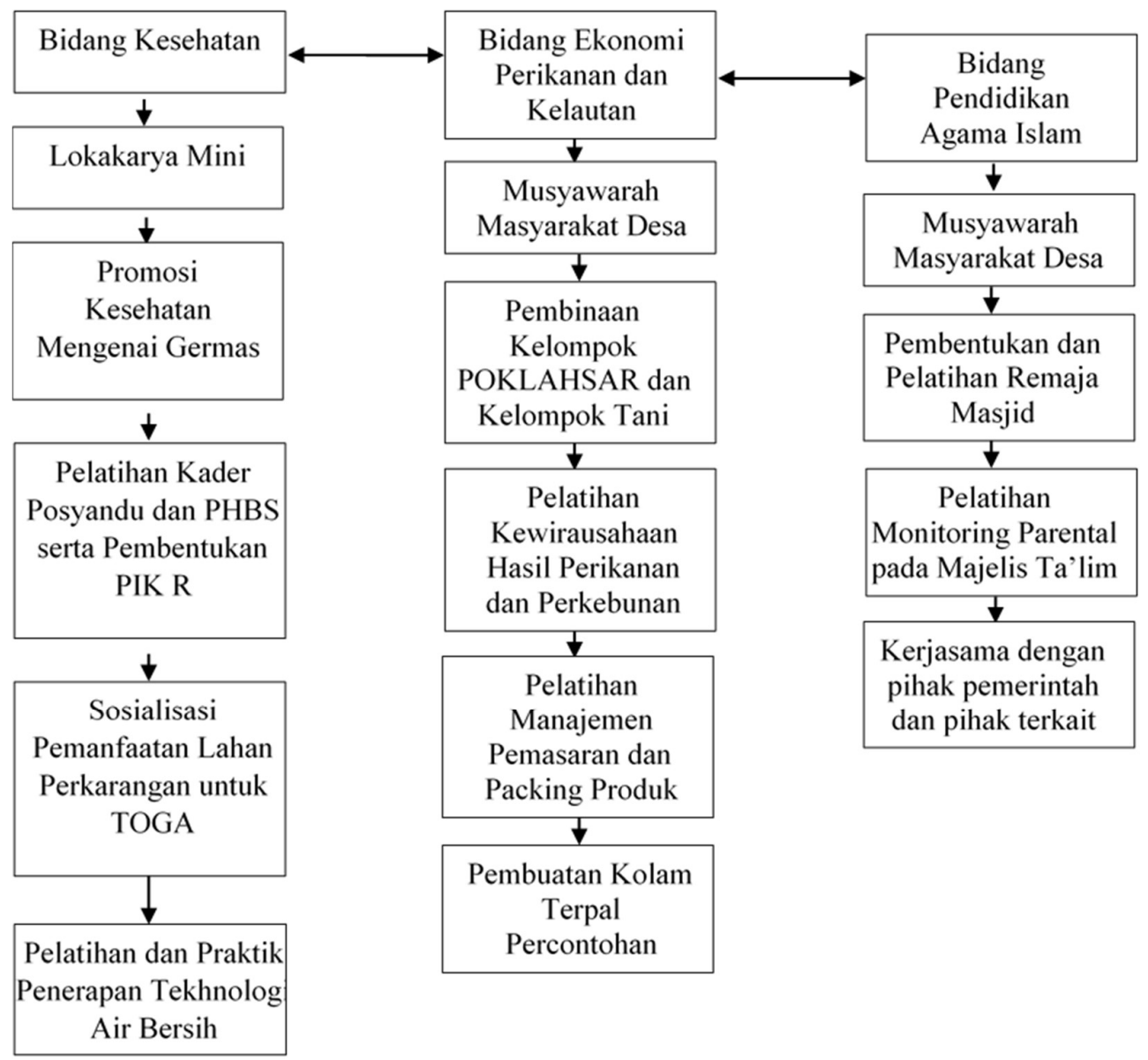




\section{HASIL DAN PEMBAHASAN}

Program kegiatan pengabdian masyarakat dilakukan di Desa Malikian Kabupaten Mempawah. Kegiatan ini dilakukan pada beberapa tempat diantaranya di Masjid Nurul Iman, SD Negeri 17 Mempawah Hilir, Kantor Desa dan Rumah Warga

\subsection{Peningkatan Pendidikan Keagamaan}

\section{a. Sosialisasi dan Pembentukan Remaja Mesjid Nurul Iman}

Pembentukan dan pelatihan remaja mesjid dilakukan apa remaja mesjid Nurul Iman yang dihadiri oleh 14 orang remaja mesjid. Kegiatan ini juga didampingi oleh pengurus mesjid sebagai pembina. Dalam kegiatan ini disampaikan pentingnya agama sebagai benteng pergaulan remaja. Remaja diharapkan dalam mengenai hal-hal yang diperbolehkan dan diharamkan oleh agama. Remaja mesjid diarahkan untuk membuat kegiatan-kegiatan yang bermanfaat sehingga remaja dapat mengisi waktunya dengan kegiatan yang positif, dengan demikian mereka mampu membentengi dirinya dari bahaya narkoba dan pergaulan bebas. Dengan demikian diharapkan dalam kurun waktu tertentu dapat meningkatkan akhlak para remaja dalam bergaul di sekolah, keluarga maupun di masyarakat, sehingga dapat mengurangi bahkan menghentikan peredaran narkoba di wilayah ini serta dapat menekan angka pernikahan usia dini. Kegiatan sosialisasi dan pembentukan remaja Mesjid Nurul Iman bisa di lihat pada gambar 1 di bawah ini
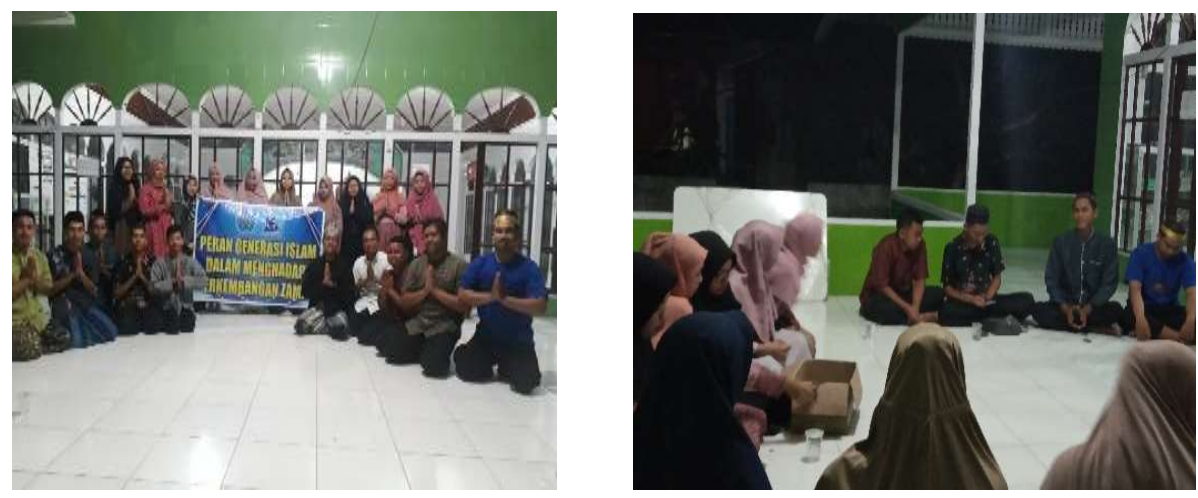

Gambar 1. Sosialisasi dan Pembentukan Remaja Mesjid Nurul Iman 
ISSN : $2620-4665$ (print)

ISSN : $2620-4673$ (online)

Website : http://jurnal.untan.ac.id/index.php/JPLP2KM

\section{b. Pembinaan Remaja Mesjid dan Tata Kelola Taman Pendidikan Quran}

Setelah pembentukan remaja mesjid, dilakukan pembinaan agar remaja mesjid tersebut dapat menyelenggarakan TPQ di Mesjid Nurul Iman. Dengan adanya TPQ ini diharapkan anak-anak banhkan orang dewasa yang belum bisa baca tulis AI Quran dapat belajar melalui sarana ini. Kegiatan ini menjadi salah satu kegiatan rutin remaja mesjid.

Dengan demikian remaja mesjid dapat meningkatkan perannya untuk membantu anak-anak belajar cara tulis Al Quran serta menghidupkan budaya islami di Desa Malikian. Kegiatan pembinaan remaja masjid dan tata kelola TPQ Nurul Iman bisa di lihat pada gambar 2 di bawah ini
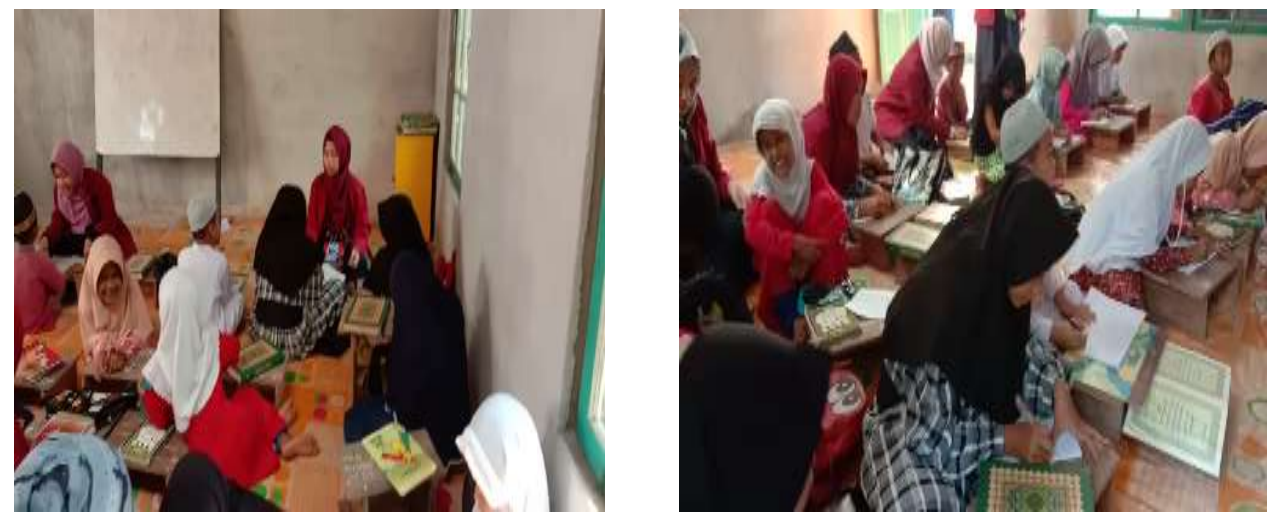

Gambar 2. Pembinaan remaja masjid dan tata kelola TPQ

\subsection{Peningkatan Gerakan Masyarakat Hidup Sehat (GERMAS)}

\section{a. Lokakarya mini}

Kegiatan lokakarya ini dilakukan untuk mengidentifikasi permasalahan yang ada, menyamakan visi misi dalam upaya mengatasi permasalahan kesehatan. Sebelum kegiatna ini dilakukan, terlebih dahulu diadakan analisa data mengenai permasalahan kesehatna di Desa Malikian. Setelah dilakukan analaisis, ternyata penyakit diare merupakan masalah utama yang sering dialami oleh masyarakat di Desa Malikian. Setelah itu dilakukan lokakarya mini untuk mengetahui resiko-resiko yang memicu timbulnya penyakit diare di masyarkat. Dengan teridentifikasinya permasalahan yang dihadapi masyarakat diharapkan sadar dan memahami pentingnya hidup bersih dan sehat dalam meningkatkan derajat kesehatan masyarakat. Penyatuan visi dan misi diharapkan mampu menjadi motivasi yang kuat dalam mensukseskan program peningkatan Gerakan Masyarakat Hidup Sehat (GERMAS) di wilayah tersebut. 


\section{b. Promosi Kesehatan PHBS, Kesehatan Reproduksi Remaja, Sanitasi Lingkungan dan Tanama Obat Keluarga.}

Kegiatan ini dilakukan pada kelompok masyarkaat seperti pengajian, pertemuan PKK, kegiatan posyandu dan di sekolah-sekolah. Masyarakat diberikan Promosi kesehatan mengenai GERMAS, PHBS, DBD, Kesehatan Reproduksi Remaja, Sanitasi Lingkungan dan Tanaman Obat Keluarga. Metode promosi kesehatan yang digunakan adalah penyuluhan kesehatan kepada masyarakat, pembagian leaflet dan pemutaran film. Kegiatan ini juga melibatkan kader posyandu dan bekerjasama dengan Puskesmas Mempawah Hilir.

\section{c. Pembuatan Media Penyaringan Air Bersih Percontohan}

Metode ini dipilih untuk menunjang kecukupan air bersih di wilayah tersebut yang umumnya adalah air asin. Metode ini diawali dengan penyuluhan dan dilanjutkan dengan pelatihan penerapan tekhnologi Saringan Air Bertingkat. Penerapan teknologi tersebut dilaksanakan di lahan masyarakat. Persiapan dan pelaksanaan pelatihan ini dilakukan dengan metode partisipatif dari masyarakat.

\section{d. Pembuatan Media dan Praktek Cuci Tangan Pakai Sabun (CTPS).}

Metode ini dipilih sebagai sarana penunjang Perilaku Hidup Bersih dan Sehat yang dimulai sejak dini dengan sasaran utamaya adalah anak-anak. Dalam kegiatna ini anak diberikan informasi mengenai pentingya mencuci tangan menggunakan sabun. Selanjutnya mereka diajarkan cara cuci tangan yang benar, selain itu mereka juga diajarkan senam cuci tangan. Anak-anak diajak untuk mengkampanyekan gerakan cuci tangan pakai sabun baik disekolah maupun dirumahnya. Kegiatan ini dilakukan di SD Negeri 17 Mempawah Hilir. Dengna demikian diharapkan dapat mengurangi kejadian penyakit seperti diare, kecacingan, disentri, dan sebagainya. Mengacu pada riset perilaku mencuci tangan dengan sabun dapat mengurangi risiko diare sebesar 42 persen sampai 47 persen, terutama pada bayi dan balita (Freeman, 2014). Kegiatan Penyuluhan PHBS (Perilaku Hidup Bersih dan Sehat) bisa di lihat pada gambar 3 di bawah ini 

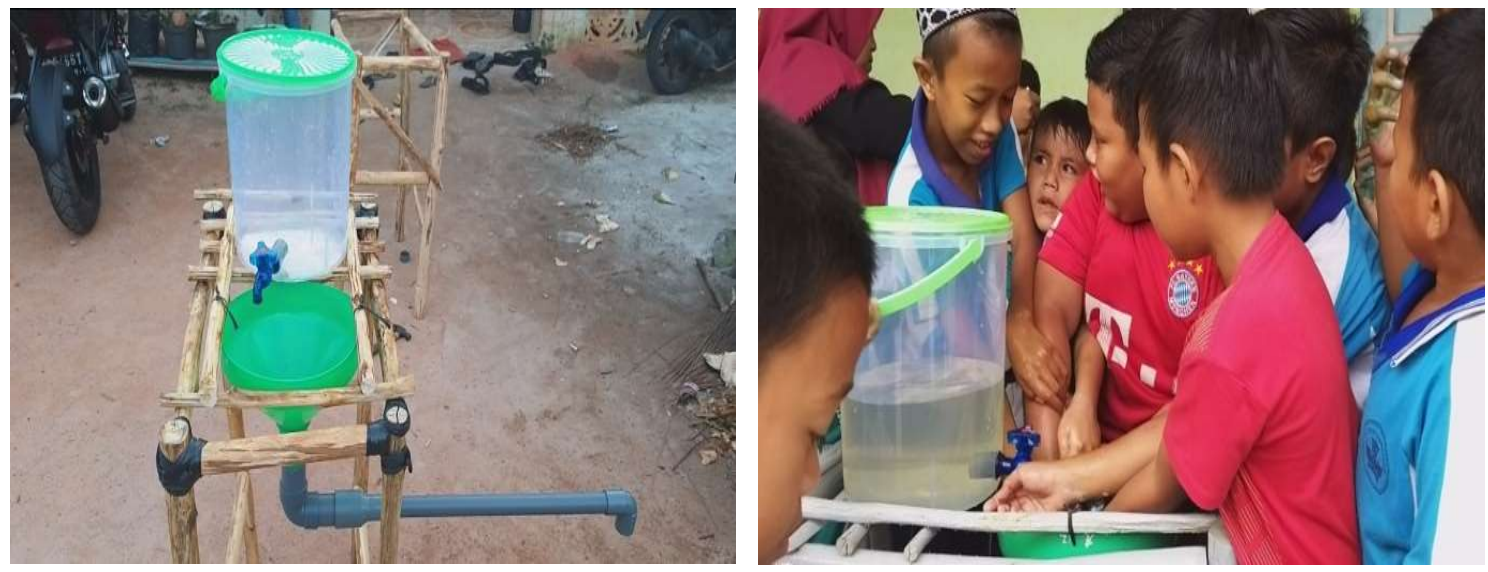

Gambar 3. Penyuluhan PHBS (Perilaku Hidup Bersih dan Sehat) di SDN 17

\subsection{Kewirausahaan Ekonomi Pertanian dan Perikanan}

\section{a. Musyawarah Masyarakat Desa}

Pelaksanaan kegiatan dalam bidang ekonomi adalah diawali dengan musyawarah masyarakat desa. Hal ini bertujuan agar komponen masyarakat mulai dari pihak desa, tokoh agama, tokoh masyarakat, kelompok masyarakat (PKK, Gapoktan, IRT, dII) dapat memberikan saran dan pendapatnya terhadap kegiatan yang akan dilaksanakan. Pada MMD ini masyarakat menyampaikan permasalahan mereka dalam pengolahan hasil alam. Terutama pada peralatan yang minim, kemasan yang kurang menarik, dan keterbatasan pemasaran produk.

\section{b. Pembinaan Kelompok Poklahsar (Kelompok Pengolah dan Pemasar).}

Metode ini dipilih karena Kelompok Pengolah dan Pemasar (Poklahsar) adalah kelompok masyarakat yang diharapkan memiliki inisiatif untuk mengembangkan kemandiriannya melalui kegiatan usaha yang produktif dalam memanfaatkan hasil perikanan dan kelautan serta perkebunan untuk diolah menjadi sesuatu yang bernilai ekonomi tinggi, seperti pembuatan nugget pisang, keripik buah kelapa dan bantal dari serabut kelapa, dan lainlain. Selain itu kelompok Tani dapat memanfaatkan lahan kosong sebagai tempat bercocok tanam sayuran, hidroponik, holtikultura dan sebagainya. Dengan adanya kelompok-kelompok mandiri tersebut diharapkan dapat meningkatkan perekonomian masyarakat. Kegiatan Pembinaan Kelompok Poklahsar bisa di lihat pada gambar 4 di bawah ini 

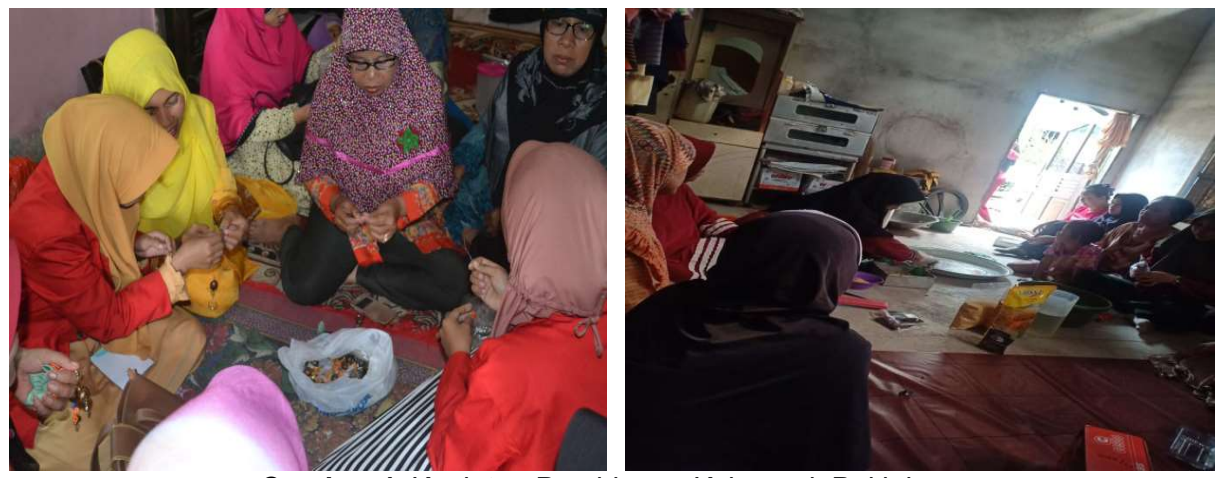

Gambar 4. Kegiatan Pembinaan Kelompok Poklahsar

c. Pelatihan pengolahan, packing produk, dan pemasaran hasil perikanan dan perkebunan.

Metode ini dipilih untuk meningkatkan pengetahuan dan keterampilan masyarakat dalam mengolah, mengkreasikan, dan memasarkan produk hasil perikanan dengan teknologi modern seperti menggunakan alat spinner dan siliser untuk packing produk sehingga dapat meningkatkan produktivitas dan nilai jual produk olahan perikanan. Mesin spinner diperlukan untuk mentiriskan minyak dari berbagai produk keripik. Mesin siller dan plastik kemasan diperlukan untuk mengemas produk menjadi kemasan yang rapi dan menarik. Selama ini mengemas kerupuk menggunakan plastik es biasa dan direkatkan dengan menggunakan api, sehingga kemasan kurang menarik. Diharapkan dengan perbaikan kemasaran produk dapat meningkatkan nilai jual dari produk tersebut. Kegiatan Pembinaan packing produk bisa di lihat pada gambar 5 di bawah ini
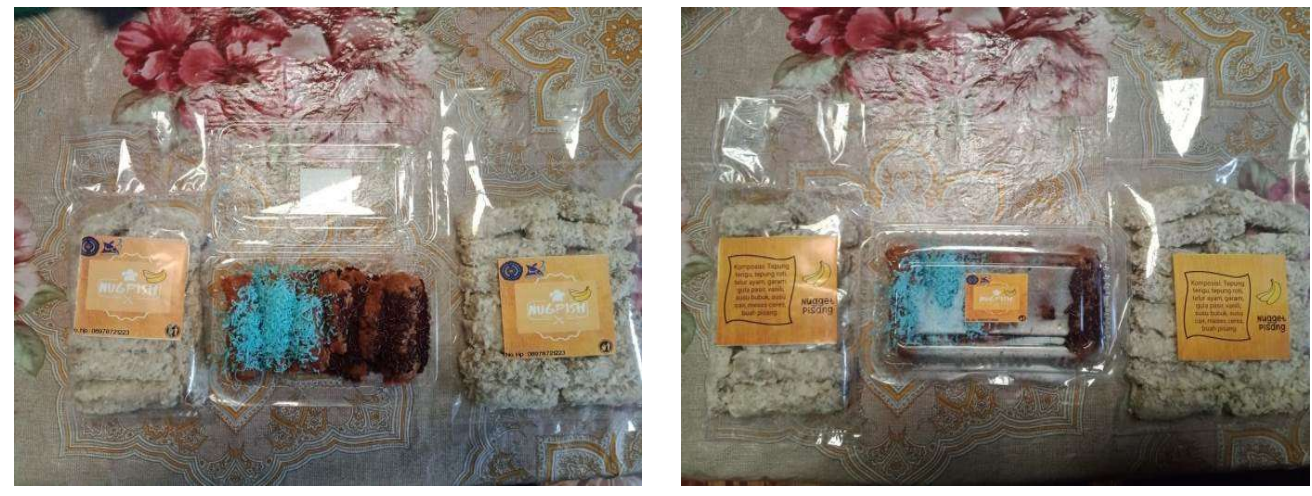

Gambar 5. Kegiatan Pembinaan packing produk 
ISSN : $2620-4665$ (print)

ISSN : $2620-4673$ (online)

Website : http://jurnal.untan.ac.id/index.php/JPLP2KM

\section{d. Pembuatan Kolam Terpal Percontohan}

Metode ini dipilih untuk meningkatkan pengetahuan dan keterampilan kelompok nelayan dalam budidaya perikanan darat, salah satunya adalah kolam terpal percontohan. Pada kegiatan ini didahului oleh sosialisasi budidaya perikanan darat. Selanjutnya diajarkan teknik pembuatan pakan ikan dengan memanfaatkan hasil alam, kegiatan ini dinilai penting karena masyarakat banyak yang menyatakan mahalnya harga pakan ikan. Setelah itu masyarakat diajarkan dan mempraktekkan pembuatan kolam terpal dan budidaya ikan nila di kolam terpal. Teknologi percontohan ini diharapkan dapat diadopsi oleh masyarakat sebagai upaya memanfaatkan potensi pekarangan agar bernilai guna dengan membudidayakan ikan di kolam terpal. Dengan demikian dapat meningkatkan ekonomi masyarakat setempat. Kegiatan pembuatan kolam terpal percontohan bisa di lihat pada gambar 6 di bawah ini
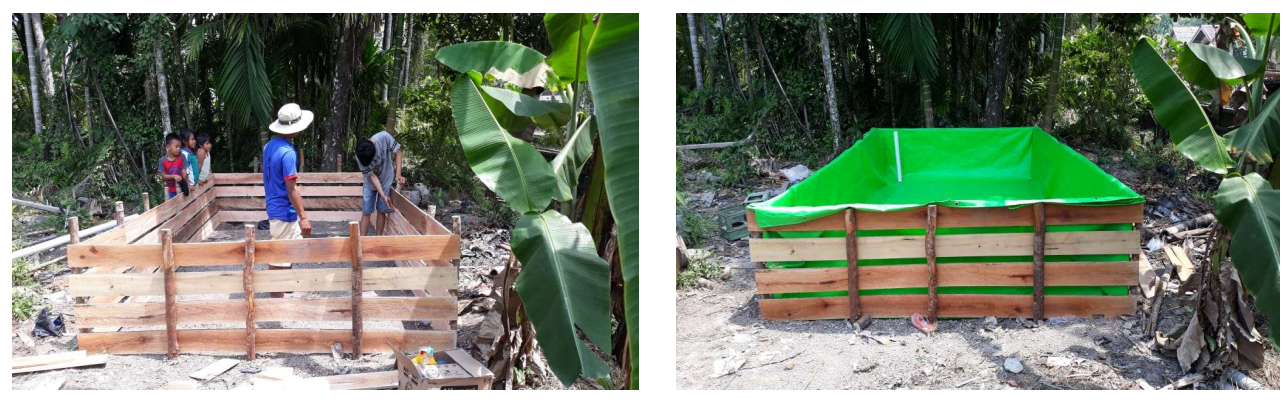

Gambar 6. Kegiatan pembuatan kolam terpal percontohan

\section{SIMPULAN DAN REKOMENDASI}

\section{SIMPULAN}

Simpulan dari program kegiatan pengabdian masyarakat ini adalah sebagai berikut:

1. Terbentuknya kelompok remaja masjid nurul iman dengan rancangan kegiatan-kegiatan yang akan dilakukan berkaitan dengan peningkatan akhlak remaja. Kelompok remaja masjid ini juga diarahkan untuk dapat menyelenggarakan TPQ di masjid nurul iman

2. Terbentuknya kelompok-kelompok masyarakat Desa Malikian yang mandiri dan produktif dalam memanfaatkan hasil perikanan, kelautan, serta perkebunan

3. Meningkatnya pengetahuan dan keterampilan masyarakat dalam mengolah, mengkreasikan, dan memasarkan produk hasil perikanan dengan teknologi modern seperti menggunakan alat spinner dan siliser untuk packing produk sehingga dapat meningkatkan produktivitas dan nilai jual produk olahan perikanan 
4. Meningkatnya pengetahuan masyarakat Desa Malikian mengenai gerakan masyarakat hidup sehat, perilaku hidup bersih dan sehat, DBD, kesehatan reproduksi remaja, sanitasi lingkungan dan tanaman obat keluarga

5. Meningkatnya pengetahuan masyarakat mengenai penerapan tekhnologi Saringan Air Bertingkat

6. Meningkatnya pengetahuan siswa SDN 17 Mempawah Hilir mengenai cuci tangan pakai sabun

\section{REKOMENDASI}

Disarankan kepada masyarakat Desa Malikian untuk dapat melanjutkan program-program pengabdian masyarakat yang sudah dilakukan seperti pelaksanaan kegiatan Taman Pendidikan Quran (TPQ), penerapan tekhnologi dalam mengolah, packing produk, dan tekhnologi saringan air bertingkat. Diharapkan juga kepada masyarakat Desa Malikian untuk dapat menerapkan perilaku hidup bersih dan sehat dan gerakan masyarakat hidup sehat.

\section{UCAPAN TERIMA KASIH}

Ucapan terimakasih disampaikan Direktorat Riset dan Pengembangan, Kemristekdikti melalui Program Kuliah Kerja Nyata-Pembelajaran Pemberdayaan Masyarakat (KKN-PPM) yang telah memberikan pendanaan dalam kegiatan ini.

\section{DAFTAR PUSTAKA}

Freeman et al. 2014. Systematic Review: Hygiene and Health: Systematic Review of Handwashing Practices Worldwide and Update of Health Effects , Tropical Medicines and International Health, Vol. 19 No. 8 (p906-916).

Kemenkes RI. 2013. Riset Kesehatan Dasar Tahun 2013. Jakarta. Kemenkes RI

Pusat Data Dan Sistem Informasi Pertanian (Pusdatin). 2014. Pemeringkatan IPM Kabupaten/Kota Di Kalbar. Pontianak: Pusdatin.

Suhartono,E. 2007. Sumber :http/ Www.Bainfokomsumut.go.id Artikel.Diakses Pada Tanggal 20 Agustus 2018.

United Nations Development Programme. 2017. Indeks Pembangunan Manusia Indonesia Meningkat Tapi Kesenjangan Masih Tetap Ada. Jakarta. http://www.id.undp.org/content/indonesia/id/home/presscenter/pressreleases/2017/03/22/indo nesia-s-human-development-index-rises-but-inequality-remains-.html. 